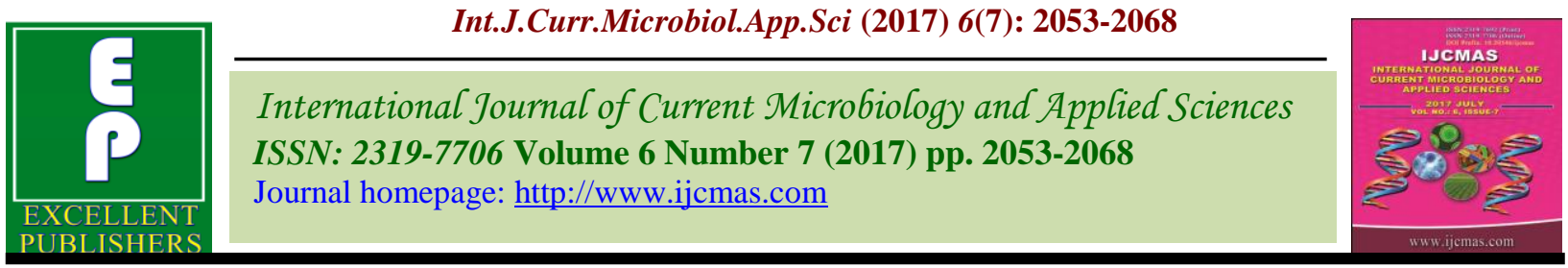

Original Research Article

https://doi.org/10.20546/ijcmas.2017.607.243

\title{
Analysis of Various Floral Components at Different Developmental Stages of the Flower
}

\author{
S.P. Adhikary* \\ Department of Botany, Aska Science College, Aska, Odisha, India \\ *Corresponding author
}

\section{A B S T R A C T}

The flower constitutes flavonoid pigments. Flavonoids belong to the polyphenol group, which includes so many colouring pigments i.e. the anthocyanidin, flavones, flavanones, flavonols, etc. Anthocyanin is among the permitted pigments that can be used for food colourants and having been considered a potential replacement for synthetic dye. Some

\section{Keywords}

Anthocyanin,

Flavonoids, Petals, Developmental stage, Pigments.

Article Info

Accepted:

21 June 2017

Available Online:

10 July 2017 other flavonoids also enhance the colour of the anthocyanin as co-pigment. The objective of this study is to analyze the flower colouring pigments and their associated phytochemicals qualitatively and quantitatively at different developmental stages i.e. the matured bud (S-2), partially open flower (S-3), fully opened flower (S-4), petals starting to decay i.e. senescent flowers (S-5) of $R$. indica, H. rosasinensis, C. ternatea and M. jalapa. Percentage of petal-water content and $\mathrm{pH}$ of the cell-sap of the petal of test flowers were determined at different developmental stages. The experimental results noticed that petal of developmental stages are altered their water content and $\mathrm{pH}$ of the cell-sap. Among the flowers, the floral pigment content in petal exhibited the following order Clitoria ternatea $>$ Rosa indica >Hibiscus rosasinensis > Mirabilis jalapa. The colour pigments viz. flavonoids, anthocyanins and phenol derivatives, protein, sugar and other nutrients present in petal of test flower might have act as potent colorant, antioxidant and neutraceuticals in food market. The procurement of color pigments from petal of the flower at appropriate level i.e. basing on developmental stage, is highly essential for further processing and manipulation through screening and evaluation. Pigment manipulation and utilization in food industry is a new field for sustainable health aspect and alternatives technology for better green environment.

\section{Introduction}

Plant pigmentation is generated by the electronic structure of the pigment interacting with sunlight to alter the wavelengths that are either transmitted or reflected by the plant tissue. Within plants, the major pigment groups show wide occurrence in the different tissues i.e. flavonoids occur in almost all tissues, carotenoids in leaves, roots, tubers, seeds, fruits and flowers, and even chlorophylls occur in flowers and fruits as well as leaves. When a petal is exposed to light, the light penetrates the pigment layer and is partially absorbed. Some of the remaining light is reflected by the sponge tissue and passes back through the pigment layer. Therefore, it is sensed by our eyes as color. The color of flowers is related to the internal or surface tissue structure of a petal and the type and amount of pigments in the petal cells. Physiological and biochemical alteration of pigment during flower development plays a major role on 
biochemical composition of petal tissue. Flavonoids, the sub cellular localization is just one of several factors that determine the behaviour of the pigment molecule in the cell and the colour generated from it (Brouillard and Dangles, 1993).

Flowering, often associated with senescence and death, is a dramatic phenomenon in monocarpic plants, where the whole plant dies after flowering or fruiting. In polycarpic plants, death is restricted to parts of the flower itself-those which senesce and abscise soon after flowering. This process represents a dramatic change in the pattern of differentiation at the shoot apex or in the axillary buds close to it. Such a complex process is regulated by both internal factors and environmental signals. In most cases, the flower is the organ with the shortest period of longevity (Halevy and Mayak, 1981), which varies greatly from species to species, but is relatively constant within any one species. The control mechanisms of flower growth and development during its life span have been reported only in few cases (Eason and Webster, 1995 and Teixeira da Silva, 2006b). Petals are the floral organs that primarily determine the commercial longevity of flowers, and as a consequence much attention has been given to the physiological, biochemical and genetic processes that occur during petal development (Eason and Webster, 1995).This developmental process is characterized by several phases including differentiation, cell division, cell enlargement and ultimate death i.e. senescence. Much of the petal growth is associated with the result of cell enlargement. Relatively little is known on the physiology of flower and petal in comparison with that of other plant organs, such as leaves. The whole natural period of growth and development is much shorter in petals than leaves and hence petals seem to be an excellent model system for the study of fundamental physiological processes. Pattern of distribution of assimilates in plants is markedly affected by the changes occurring during transition from vegetative to reproductive phase (Halevy and Mayak, 1981) and the process controlling flower development regulates the partitioning of assimilates between the flower and rest of the shoot system. The developing flowers act as a sink and the rate of carbohydrate flow from source to sink is related to the rates of activities of enzymes like invertase. Developing corolla in roses continues to import dry matter throughout its development and reducing sugars and starch accounts for $50 \%$ of its dry weight (Ho and Nichols, 1977).Therefore, hydrolysis of stored starch is probably associated with flower opening so far as a decrease in water potential favours influx of water with the corolla tissue and promotes cell enlargement.

Basing on the above facts and views, the aim of this investigation was to evaluate the biochemical changes (petal-water content and $\mathrm{pH}$ of cell-sap of petals) and concentration of different flowering pigments (total anthocyanin, flavonoid, sugar and protein content) in petals of the four different types of flowers i.e. red (Hibiscus rosasinensis and Rosa indica), pink (Mirabilis jalapa) and blue (Clitorea ternatea) during different developmental stages i.e. from under developed S-2 (matured-bud i.e. early developmental stage), S-3 (partially opened flower stage), S-4 (fully opened stage) and S5 (partly decayed late developmental stage).

\section{Materials and Methods}

South-east Odisha is a vast area constituting some areas of Puri, Khurda and Ganjam districts. As Ganjam district covers major area, some places nearer to Berhampur University were selected as study sites. A brief description of study sites are described below i) Berhampur University campus, a 
coastal area is situated 3-4 km away from the sea coast of Bay of Bengal (Gopalpur) ii) Berhampur city is also situated at about 12 $\mathrm{km}$ away from Gopalpur sea coast and iii) Aska Science College campus which is the central part of south-east Odisha, is at $50 \mathrm{~km}$ away from the sea coast.

\section{Collection and selection of the test flowers}

In this piece of investigation, four types of flowers of 3 different colours i.e. red (Hibiscus rosasinensis and Rosa indica), pink (Mirabilis jalapa) and blue (Clitorea ternatea) were used to study the flower colouring pigments and their associated phytochemicals, qualitatively and quantitatively, at different developmental stages such as at the matured bud (S-2), partially open flower (S-3), fully opened flower (S-4) and petals starting to decay i.e. senescent flowers (S-5). Percentage of petalwater content and relative changes in the $\mathrm{pH}$ of the cell-sap of the petals were also determined at above mentioned developmental stages. The flowers of Hibiscus rosasinensis, Rosa indica, Clitorea ternatea and Mirabilis jalapa, selected for investigation, were randomly collected at different developmental stages as mentioned earlier. The specimens were collected in the early morning except Mirabilis jalapa which were collected in late afternoon. After washing them thoroughly in tap water followed by distilled water and soaked in blotting paper were kept in clear domed trays overnight under refrigerated condition in dark until the onset of experimental processes.

\section{Water content of petals}

Fresh weight of the petals was recorded immediately after plucking and removing from flower bud and flowers. Then the dry weight (dry wt.) of petals was recorded after drying them in an incubator maintained at 60 $\pm 2^{\circ} \mathrm{C}$ for 24 hours. Percentage of petal-water content was determined following the method of Valentina et al., (2010) and expressed as per the formulae given below. Each set had 5 replicates.

$\%$ of water content $=$

$\frac{[(\text { Fr.wt of the petals }- \text { dry wt. of the petals })]}{\text { Fr.wt. of the petals }} \times 100$

\section{pH of the petal cell-sap}

The determination of relative changes in the $\mathrm{pH}$ of the cell-sap of the petals were done by macerating $0.5 \mathrm{~g}$ of petals collected from different flowers at various stages, in $5 \mathrm{ml}$. of distilled water in a sterilized mortar and pestle. Then the homogenates were centrifuged at $1000 \mathrm{rpm}$ at room temperature $\left(30 \pm 2^{0 \mathrm{C}}\right)$ for 10 minutes. Then the $\mathrm{pH}$ of the supernatants was measured with the help of a digital $\mathrm{pH}$ meter followed by the method adopted by Valentina et al., (2010).

\section{Extraction and estimation of total anthocyanin content}

\section{Extraction}

The total anthocyanin pigments were extracted from petals of each of the individual flowers at different developmental stages and estimated as per the methods adopted by Harborne (1998). One gram petal materials of each test flowers collected from different developmental stages were taken in separate conical flasks, stoppered with rubber cork and allowed to leach in $10 \mathrm{ml}$ of $0.1 \%$ $\mathrm{HCl}$ in $80 \%$ methanol (v/v) for 3 hours at room temperature in darkness. Then the petals were homogenized thoroughly in a clean sterilized mortar and pestle. The homogenate was then filtered through Whatman filter paper (No.110). The remaining residues were washed with $0.01 \% \mathrm{HCl}$ in $80 \%$ methanol until clear filtrate was obtained. The pooled 
filtrates were then concentrated using a rotary evaporator at $30 \pm 1^{\circ} \mathrm{C}$. Then the concentrated substances were dissolved in acidified water $[0.01 \% \mathrm{HCl}$ in D.W (v/v)] and the solution so obtained was made up to a known volume (10 $\mathrm{ml}$ ) with acidified water and stored at $4 \pm 1^{\circ} \mathrm{C}$. The resultant solution served as the floral pigment extract.

\section{Estimation}

The total anthocyanin content in the petal tissues of test flowers was estimated as per the method described by Chirboga and Francis (1970). The total pigment extracts of different flower of various developmental stages obtained as described above, were taken out of the fridge and allowed to defrost at the room temperature for 30 minutes.

In one set, to $1 \mathrm{ml}$ of each extract taken separately in $10 \mathrm{ml}$ conical flask, $4 \mathrm{ml}$ of buffer solution of $\mathrm{pH} 1.0(0.13 \mathrm{M} \mathrm{HCl}-0.05 \mathrm{M}$ $\mathrm{KCl})$ was added and in second set, to $1 \mathrm{ml}$ of extract, $4 \mathrm{ml}$ of buffer solution of $\mathrm{pH} 4.5$ (0.05M HCl-0.05 $\mathrm{M} \mathrm{CH}_{3} \mathrm{COONa}$ ) was added. The mixture of buffers and samples were equilibrated in dark for one hour separately and their absorbance were measured at 520 $\mathrm{nm}$ by spectrophotometer (Elico-digital, Model CL-27). Cyanidin-3-glucoside was used as standard. The data are expressed in $\mathrm{mg} / \mathrm{g}$ fr.wt of the petal tissues. The total anthocyanin content was calculated by following the formulae adopted by Fuleki and Francis (1968).

Total anthocyanin content $=$ $\frac{\left[\left(\mathrm{A} \times \mathrm{MW} \times \mathrm{DF} \times 10^{3}\right)\right]}{\varepsilon \times \mathrm{L}} \mathrm{mg} / \mathrm{g}$ fr.w t.

Where,

$\mathrm{A}=$ Absorbance $=\left(A_{520 n m}\right.$ at $\mathrm{pH} 1.0-A_{520 \mathrm{~nm}}$ at $\mathrm{pH} 4.5$ ),
$\mathrm{MW}=$ molecular weight $=(449.2 \mathrm{~g} / \mathrm{mol})$ for cyanidin-3-glucoside (cyd-3-glu)

$\mathrm{DF}=$ dilution factor $(0.2 \mathrm{ml}$. sample in $2 \mathrm{ml}$. $\mathrm{DW}=10$ )

$\mathrm{L}=$ path length of sample in cuvette in $\mathrm{cm}=1$ $\mathrm{cm}$

$\varepsilon=26900$ (Molar extinction coefficient, in L . $\mathrm{mol}^{-1} \cdot \mathrm{cm}^{-1}$, for Cyd-3-glu.) and

$10^{3}=$ factor for conversion from $\mathrm{g}$ to $\mathrm{mg}$.

Extraction and estimation of total flavonoid contents

\section{Extraction}

Petals of different test flowers at various developmental stages as mentioned earlier, were collected from all the study areas, washed thoroughly in distilled water, soaked on blotting paper under shade in laboratory at $25 \pm 2{ }^{\circ} \mathrm{C}$, allowed to fully dried and then were ground into fine powders using a sterilized mortar and pestle.

There after the floral powders were stored in air tight bottles in cold at $4 \pm 1{ }^{\circ} \mathrm{C}$ in the laboratory for further use when required. The flavonoid was extracted as per the method adopted by Khatiwora et al., (2010).

0.2 grams of the petal powders of each test flower taken out of the fridge homogenized with sterilized mortar and pestle in 5-10 $\mathrm{ml}$ of $80 \%$ methanol and then filtered through Whatman (No.1) filter paper.

The left over residues were washed with $80 \%$ methanol until clear filtrate was obtained. The filtrates were pooled together and made to 20 $\mathrm{ml}$ with $80 \%$ methanol which served as flavonoid extract. 


\section{Estimation}

The total flavonoid content was estimated by following the aluminum chloride method adopted by Khatiwora et al., (2010). For estimation of total flavonoids contents, $1 \mathrm{ml}$ of extract of each test flowers were taken in test tubes and $3 \mathrm{ml}$ of $80 \%$ methanol was added to each test tube separately. Then 0.2 $\mathrm{ml}$ of $10 \%$ Aluminium chloride, $0.2 \mathrm{ml}$ of $1 \mathrm{M}$ Potassium Acetate and $5.6 \mathrm{ml}$ of distilled water were added, mixed thoroughly and allowed for reaction at room temperature for 30 minutes. A blank was prepared in a similar way by replacing aluminium chloride with distilled water. The absorbance of the reaction mixtures was measured at $415 \mathrm{~nm}$ with UV visible spectro-photometer. A standard calibration plot was generated at $415 \mathrm{~nm}$ using $0-20 \mathrm{mg} / \mathrm{ml}$ concentrations of Quercetin in distilled water.The total flavonoid content (TFC) was calculated by using the following formula suggested by Kiranmai et al., (2011). The data are expressed in $\mathrm{mg} / \mathrm{g}$ dry wt. of petal tissues.

The total flavonoid content $($ TFC $)=$

$$
\frac{\mathrm{R} \times \mathrm{DF} \times \mathrm{V}}{W} \mathrm{mg} / \mathrm{g} \text { dry w t. }
$$

[Where, R-Concentration obtained from the standard curve, D.F (Dilution factor) $=10, \mathrm{~V}=$ Volume of stock Solution $=20 \mathrm{ml}, \mathrm{W}=$ Weight of petal powder used in this experiment $=0.2 \mathrm{~g}]$.

\section{Extraction and estimation of total sugar contents}

\section{Extraction}

The floral powder of dried petals of different test flowers obtained during flavonoid extraction as mentioned in the section 2.2.2.4, were used for sugar extraction following the method of Mahadevan and Sridhar (1998).
$100 \mathrm{mg}$ of petal powder of each test flowers were taken and homogenized with 80\% ethanol (v/v) and centrifuged at $4000 \mathrm{rpm}$ at $25 \pm 1{ }^{\circ} \mathrm{C}$ for 15 minutes and the supernatants were collected. The process was repeated for three times until a colourless supernatant solution was obtained. All the supernatants were pooled together and allowed to evaporate in a water bath till the volume was reduced to slurry of 1 or $2 \mathrm{ml}$. To this slurry distilled water was added to make a definite volume $(10 \mathrm{ml}$.) which served as extract of total sugar.

\section{Estimation}

For estimation of total sugar, to $1 \mathrm{ml}$ of alcoholic petal extract of each test flower $4 \mathrm{ml}$ of anthrone reagent ( $2 \mathrm{~g} / \mathrm{l}$ concentrated $\mathrm{H}_{2} \mathrm{SO}_{4}$ ) was added carefully from the side of each test tube separately and mixed thoroughly by shaking. The test tubes were placed in a boiling water bath for 10 minutes with glass marble balls on top to prevent loss of water by evaporation. The reaction mixtures were then cooled and their optical densities (O.D) were recorded at $625 \mathrm{~nm}$ with the help of a spectrophotometer following the method adopted by Mahadevan and Sridhar (1998). D-Glucose was used for the standard curve. For blank, $1 \mathrm{ml}$ of distilled water was used in place of extract. The total sugar content was expressed in $\mathrm{mg} / \mathrm{g}$ dry wt.

\section{Extraction and estimation of protein}

\section{Extraction}

The extraction of total protein was performed as per the method suggested by Wasim Shahri et al., (2011). One g petals of each test flowers of different developmental stages were taken separately, after washing with DW and soaking in blotting paper those were homogenized with $10 \mathrm{ml}$ of $80 \%$ methanol in a sterilized mortar and pestle for 5 minutes at 
room temperature $\left(25 \quad \pm 1 \quad{ }^{\circ} \mathrm{C}\right)$. The homogenates were then centrifuged at 3000 rpm for 10 minutes at $25 \pm 1{ }^{\circ} \mathrm{C}$. Then to the pallets $5 \mathrm{ml}$ of ethyl acetate $(99 \%)$ was added and again centrifuged at $4000 \mathrm{rpm}$ for 15 minutes at $25 \pm 1{ }^{\circ} \mathrm{C}$.

There after the residues were treated with 5 $\mathrm{ml}$ of $5 \%$ sodium sulphite (w/v) and $0.1 \mathrm{~g}$ of polyvinyl pyrrolidone (PVP) and again centrifuged as mentioned above. There after the pellet was treated with 2 to $3 \mathrm{ml} 0.1 \mathrm{~N}$ $\mathrm{NaOH}$ and centrifuged at $4000 \mathrm{rpm}$ for 15 min at $25 \pm 1{ }^{\circ} \mathrm{C}$. Supernatants so collected were used for protein estimation.

\section{Estimation}

The estimation was carried out as per the procedure suggested by Lowry et al., (1951). To $0.5 \mathrm{ml} \mathrm{NaOH}$ extract, $2.5 \mathrm{ml}$ alkaline reagent (mixture of $50 \mathrm{ml}$ of $\mathrm{Na}_{2} \mathrm{Co}_{3}$ in $0.1 \mathrm{~N}$ $\mathrm{NaOH}$ and $1 \mathrm{ml}$ of mixture containing equal amount of $1 \% \mathrm{CuSO}_{4}$ and $2 \%$ Sodium Potassium tertarate and $0.5 \mathrm{ml}$ Folin-Phenol reagent were added.

This reaction mixture were allowed to stand at room temperature $30 \pm 1{ }^{\circ} \mathrm{C}$ for 30 minutes and the optical density (O.D) of the reaction mixtures were measured at $620 \mathrm{~nm}$. BSA was used as the reference standard. Equal amount of $0.1 \mathrm{NaoH}$ in place of protein extract and Folin-phenol reagent were run parallel as blank. Proteins content was expressed in $\mathrm{mg} / \mathrm{g}$ fresh wt.

\section{Results and Discussion}

The data on changes in petal-water content, $\mathrm{pH}$ of cell-sap of petals, and concentration of different flowering pigments (total anthocyanin, flavonoid, sugar and protein content at different developmental stages i.e. S-2, S-3, S-4 and S-5 stages obtained during experimentation are given below.

\section{Change in water-content of petal of test flower}

The water content in petals of all analyzed test flowers gradually increased from S-2 stage to S-4 stage and then decrease which varied from 1 to $9 \%$ in all the test flowers. In Rosa indica the drop was very less i.e. $1 \%$ compared to the drops in Clitorea ternatea (5\%), Hibiscus rosasinensis (9\%) and Mirabilis jalapa (5\%) from early developmental (S-2) stage to fully developed (S-5) stage. The water content in petals increased from $50 \pm 2.2$ to $65 \pm 2.1 \%$ in Rosa indica, $40 \pm 2.2$ to $50 \pm 2.3 \%$ in Clitorea ternatea, $45 \pm 2.1$ to $50 \pm 2.2 \%$ in Hibiscus rosasinensis and $40 \pm 2.2$ to $42.2 \pm 2.4 \%$ in Mirabilis jalapa from S-2 to S-3 stages, whereas at fully opened stage $(\mathrm{S}-4)$ the water content in petals increased from $65 \pm 2.1 \%$ to $69 \pm 2.2 \%, 50 \pm 2.3$ to $65 \pm 2.2 \%, 50 \pm 2.2$ to $69 \pm 2.1 \%$ and $42.2 \pm 2.4$ to $50 \pm 2.2 \%$ respectively from S-3 stages of all the test flowers (Table 1). The degree of water retention capacity of the test flower were Rosa indica > Hibiscus rosasinensis > Clitorea ternatea $>$ Mirabilis jalapa .

\section{Change in the $\mathrm{pH}$ of cell-sap of petals in test flowers}

The $\mathrm{pH}$ of cell-sap of petals of Rosa indica was $4.6 \pm 0.08,4.80 \pm 0.06,4.86 \pm 0.05$ and $4.88 \pm 0.07$ in S-2, S-3, S-4 and S-5 stages respectively. Similar results were found in Clitoria ternatia $(5.2 \pm 0.07,5.4 \pm 0.07,5.52 \pm$ 0.08 and 5.56 \pm 0.08 ), Hibiscus rosa-sinensis (3.6 $\pm 0.08,4.2 \pm 0.07,4.36 \pm 0.05$ and $4.42 \pm$ $0.06)$ and Mirabilis jalapa (4.12 $\pm 0.06,4.2 \pm$ $0.06,4.52 \pm 0.06$ and $4.54 \pm 0.07$ ) in S-2, S-3, S-4, and S-5 stages respectively. In all analyzed test flowers, the $\mathrm{pH}$ of petal cellsaps at different developing stages were increased gradually from early developmental stage of flower (S-2 stage) to partly senescent flower (S-5 stage) (Table 1). No significant 
correlations between changes in $\mathrm{pH}$ at different developmental stage in all test flowers were noticed.

\section{Changes in total anthocyanin contents in petals of all the test flowers}

In present investigation, it was observed that, the total anthocyanin contents at S-3 stage in R.indica and H.rosasinensis and S-4 stage in C.ternatea and M.jalapa exhibited maximum amount and the values were $0.898 \pm 0.03$, $1.432 \pm 0.05,2.404 \pm 0.04$ and $3.494 \pm 0.04$ $\mathrm{mg} / \mathrm{g}$ fr. wt. respectively. From table 1 , it can be noticed that maximum amount of anthocyanin content $(3.494 \pm 0.04 \mathrm{mg} / \mathrm{g}$ fr.wt.) was present in $M$. jalapa followed by $C$. ternatea $(2.404 \pm 0.04), \quad H$. rosasinensis $(1.432 \pm 0.05)$ and $R$. indica $(0.898 \pm 0.03)$. At S-4, S-4, S-3 and S-3 stages respectively. In respect to developmental stages, more anthocyanin were found at S-3 and S-4 stages and less in S-2 stage irrespective of test flowers. The total anthocyanin content in petal of test flowers was in the following order: In Rosa indica and Hibiscus rosasinensis it was $\rightarrow \mathrm{S}-3>\mathrm{S}-4>\mathrm{S}-5>\mathrm{S}-2$; but in Clitorea ternatea and Mirabilis jalapa the trend was $\rightarrow \mathrm{S}-4>\mathrm{S}-5>\mathrm{S}-3>\mathrm{S}-2$.

\section{Changes in flavonoid contents in petals of test flowers}

The light-ivory-coloured co-pigments associated with anthocyanin are the flavonoid pigments which intense the colour of the flowers. It was observed that, the total flavonoid content in petals of all the test flowers was maximum in S-4 stage and minimum in S-2 stage. The degree of total flavonoid content was in the following order: S-4 > S-5 > S-3 > S-2 stages.

In the test flowers, the maximum and minimum flavonoid contents at stage $\mathrm{S}-4$ and S-2 were as follows: Rosa indica $\rightarrow$
$10.06 \pm 0.5$ and $7.80 \pm 0.2 ;$ Clitorea ternatea $\rightarrow 12.96 \pm 0.5$ and $8.80 \pm 0.3$; Hibiscus rosasinensis $\rightarrow 10.02 \pm 0.4$ and $6.20 \pm 0.4$ and Mirabilis jalapa $\rightarrow 12.04 \pm 0.3$ and $10.32 \pm 0.3$ $\mathrm{mg} / \mathrm{g}$ dry wt. respectively. Petal of S-3 and S5 stages showed intermediate values in all test flowers (Table 2).

\section{Changes total sugar contents in petals of test flowers}

Among the different developmental stages of test flowers, maximum amount of sugar content were recorded at S-4 stage in petals of test flowers. In Rosa indica, Hibiscus rosasinensis, Clitoria ternatae and Mirabilis jalapa, the amount of sugar content were recorded as $2.360 \pm 0.05,2.340 \pm 0.05,2.220$ \pm 0.04 , and $1.460 \pm 0.03 \mathrm{mg} / \mathrm{g}$ dry wt. respectively whereas minimum amount of $2.140 \pm 0.04,1.980 \pm 0.03,1.920 \pm 0.03$ and $1.298 \pm 0.02 \mathrm{mg} / \mathrm{g}$ dry wt. were recorded at $\mathrm{S}$ 2 stage. The sugar content at S-3 and S-5 stages was found to be in intermediate level. The order of total sugar content was: S-4 $>$ S$3>\mathrm{S}-5>\mathrm{S}-2$ in petals of tested flowers (Table 2).

\section{Change in protein contents in petals of test flowers}

Change in total protein content in test flower exhibited more or less same trends as were noticed in case of total sugar content. The order of total protein content (mg/g fr. wt.) was in the following order i.e. in Rosa indica $\rightarrow$ S-2 $(0.39 \pm 0.02)>\mathrm{S}-3(0.38 \pm 0.01)>$ $\mathrm{S}-4(0.36 \pm 0.01)>\mathrm{S}-5(0.30 \pm 0.01)$, Clitorea ternatea $\rightarrow \mathrm{S}-2(0.28 \pm 0.01)>\mathrm{S}-3(0.25 \pm$ $0.02)>\mathrm{S}-4(0.23 \pm 0.01)>\mathrm{S}-5(0.22 \pm 0.01)$, Hibiscus rosasinensis $\rightarrow \mathrm{S}-2(0.36 \pm 0.01)>\mathrm{S}-$ $3(0.34 \pm 0.01)>\mathrm{S}-4(0.32 \pm 0.02)>\mathrm{S}-5(0.30$ $\pm 0.01)$ and Mirabilis jalapa $\rightarrow$ S-2 $(0.26 \pm$ $0.01)>\mathrm{S}-3(0.25 \pm 0.01)>\mathrm{S}-4(0.24 \pm 0.02)>$ S-5 (0.22 \pm 0.01$)$ (Table 2). Total protein content was found to be maximum in petal of 
Rosa indica flower followed by Hibiscus rosasinensis, Clitoria ternatae and Mirabilis jalapa.

Flowering process is considered as a dramatic phenomenon in monocarpic plants, where the whole plant dies after flowering or fruiting, while in polycarpic plants, death is restricted to parts of the flower itself, where flowers senesce and abscise soon after flowering. This process represents a dramatic change in the pattern of differentiation at the shoot apex or in the axillary buds close to it. Such a complex process is regulated by both internal factors and environmental signals. In most cases, the flower is an important organ with the shortest period of longevity (Halevy and Mayak, 1981), which varies greatly from species to species, but is relatively constant within any one species. The control mechanisms of flower growth and development during its life span have been reported and reviewed only in few cases (Eason and Webster, 1995). Petals are the floral organs that primarily determine the commercial longevity of flowers and as a consequence much attention has been given to the physiological, biochemical and genetic processes that occur during petal development (Eason and Webster, 1995). This developmental process is characterized by several phases including differentiation, cell division, cell enlargement and ultimate death i.e. senescence. Much of the petal growth is associated with the result of cell enlargement. Relatively little is known on the physiology of flower and petal in comparison with that of other plant organs, such as leaves. The whole natural period of growth and development is much shorter in petals than leaves and hence petals seem to be an excellent model system for the study of fundamental physiological processes. Pattern of distribution of assimilates in plants is markedly affected by the changes occurring during transition from vegetative to reproductive phase (Halevy and
Mayak, 1981) and the process controlling flower development regulating the partitioning of assimilates between the flower and rest of the shoot system. The developing flowers act as a sink and the rate of carbohydrate flow from source to sink is related to the rates of activities of enzymes like invertase. Developing corolla in roses continues to import dry matter throughout its development and reducing sugars and starch accounts for $50 \%$ of its dry weight (Ho and Nichols, 1977). Therefore, hydrolysis of stored starch is probably associated with flower opening so far as a decrease in water potential favours influx of water with the corolla tissue and promotes cell enlargement.

The biochemical composition of four test flowers during different developmental stages from under developed stage (S-2) to fully formed and partly decayed stages (S-5) involved variation in water content of the petals, $\mathrm{pH}$ of the cell-sap, total anthocyanin, flavonoid, sugar and protein contents in the petals. The discussions based on results obtained are as follows:

\section{Variation in water content of petals}

The increase in fr. wt. of flowers, attributed to a high percentage of water content in enlarged cells of partly open flower (S-3) and fully opened flowers (S-4) in most of the analyzed test flowers, suggest that cell expansion and water accumulation in vacuoles play an important role in the flower development. Petal development can be divided into two main phases: (a) slow growth phase resulting mainly from cell divisions and (b) a rapid growth phase resulting cell expansion (Martin and Gerats, 1993).

The increase in fresh weight, dry weight and moisture content from S-2 to S-3 stages, suggests the importance of cell expansion phase in the flower development. The water- 
content in petals of all analyzed test flowers was gradually increased from $\mathrm{S}-2$ stage to subsequent developmental stages of S-3 and $\mathrm{S}-4$, but a decreased trend was observed in S5 stage in all the test flowers. Similar results were reported in flowers of Rosa damascena and Rosa bourboniana by Sood et al., (2006) and Schmitzer et al., (2010).

In Rosa indica the decrease of water content (\%) was very less compared with the petals of Mirabilis jalapa flower followed by Hibiscus rosasinensis and Clitorea ternatea after S-4 stages. The increase in fr. wt. of the test flowers can be attributed to a high percentage of water content in enlarged cells of partly opened flowers of S-3 stage and fully opened flowers of S-4 stage suggest that cell expansion and water accumulation in vacuoles play an important role in the flower development.

The developing flower act as a sink and the rate of carbohydrate flow from source to sink is related to hydrolysis of stored starch which probably be associated with opening of flower and other developmental activities.

The decrease in water potential favors influx of water within the corolla tissue and promotes cell enlargement with full turgid cells and the role of sugar in flower development is multifunctional.

They act as an energy source, osmotic regulators and precursors for various metabolic processes. Hence, the increased osmoticum in the petals might have regulated the driving force for floral development and expansion.

\section{Variation in pH of the cell-sap of petals}

In all analyzed test flowers, the $\mathrm{pH}$ level of the cell-sap in developing flowers increased from bud stage (S-2) to senescent stage (S-5) which suggests that during cell elongation the water-potential drops might have caused by increase in $\mathrm{pH}$ of the cell-sap. Accumulated water in vacuoles hydrolyse the starch to sugars, as a result, the sugar level within the cell-sap increased and that might have lead to increase the $\mathrm{pH}$ of cell-sap. Asen et al., (1971) reported that the post-harvest bluing in petals of most of the flowers may be due to the increase in $\mathrm{pH}$ level.

The similar results were also found in petals of test flowers which might be due to the formation of complexes with quercetin derivates when $\mathrm{pH}$ was increased. Generally, a weekly acidic vacuolar $\mathrm{pH}$ is most often maintained in flower petal cells and it affects anthocyanin stability even with a slight modification (Kirca et al., 2007 and Schmitzer et al., 2010).

Ageing of petals, resulting in an increase of cell-sap $\mathrm{pH}$, is one of the physiological and bio-chemical processes accompanying to senescence (Kuiper et al., 1996).

In all analyzed test flowers, increase of $\mathrm{pH}$ level of cell-sap of developing flowers from early developmental stage (S-2) to senescent stage (S-5), might be due to accumulation of nitrogenous compounds produced from proteolysis of various macromolecules and high turnover of intermediate molecules produced by several physiological and metabolic activities of the organelle tissues.

\section{Variation in total anthocyanin and flavonoid content in petals}

Within plants, the major pigment groups show wide occurrence in the different tissues. For example, flavonoids occur in almost all tissues; carotenoids in leaves, roots, tubers, seeds, fruits and flowers and even chlorophylls occur in flowers and fruits as well as leaves. 
Within tissues, there is often distinct localisation of pigment types in different cell layers. For example, anthocyanins are typically found in epidermal cells in petals and sub-epidermally in leaves.

The sub-cellular localisation of different pigment groups is also generally distinct. The chlorophylls and carotenoids are principally lipid-soluble and plastid located pigments, although there are examples of water-soluble carotenoids, at least some of which are located in the vacuoles via plastid-vacuole interactions (Bouvier et al., 2003a).

The betalains are also water-soluble and vacuolar-located pigments while flavonoids occur in many sub-cellular locations, as well as extracellularly, the coloured flavonoids are principally found in the vacuoles (Bohm,
1994). Flavonoids, the sub-cellular localisation are just one of several factors that determine the behaviour of the pigment molecule in the cell and the colour generated from it (Brouillard and Dangles, 1993).

The mechanisms by which pigments such as the flavonoids are directed to the correct subcellular compartments are poorly defined, although some of the steps for anthocyanins have been elucidated (Winefield, 2002).

Interactions of plant pigments with other cellular components have been well defined for flavonoids and other small molecules (Brouillard and Dangles, 1993) and it is known that both flavonoids and carotenoids interact with specific proteins in the cell (Vishnevetsky et al., 1999 and Winefield, 2002).

Table.1 Variation in water content of petals, $\mathrm{pH}$ of the cell-sap, and Total anthocyanin content in petals of test flowers at different developmental stages

(Values are means of 5replicates \pm S.E.M)

\begin{tabular}{|c|c|c|c|c|}
\hline $\begin{array}{l}\text { Name of } \\
\text { flower species }\end{array}$ & $\begin{array}{c}\text { Develop- } \\
\text { mental } \\
\text { stages }\end{array}$ & $\begin{array}{l}\text { Water contents } \\
\text { of petals }(\%)\end{array}$ & $\begin{array}{l}\text { pH of the cell- } \\
\text { sap of petals }\end{array}$ & $\begin{array}{c}\text { Total anthocyanin } \\
\text { content (mg/g } \\
\text { fr.wt) }\end{array}$ \\
\hline \multirow[t]{4}{*}{ Rosa indica } & S2 & $50 \pm 2.2$ & $4.60 \pm 0.08$ & $0.716 \pm 0.04$ \\
\hline & S3 & $65 \pm 2.1$ & $4.80 \pm 0.06$ & $0.898 \pm 0.03$ \\
\hline & $\mathrm{S} 4$ & $69 \pm 2.2$ & $4.86 \pm 0.05$ & $0.834 \pm 0.04$ \\
\hline & S5 & $68 \pm 2.1$ & $4.88 \pm 0.07$ & $0.732 \pm 0.03$ \\
\hline \multirow{4}{*}{$\begin{array}{l}\text { Clitoria } \\
\text { ternatea }\end{array}$} & S2 & $40 \pm 2.2$ & $5.20 \pm 0.07$ & $1.102 \pm 0.03$ \\
\hline & S3 & $50 \pm 2.3$ & $5.40 \pm 0.07$ & $2.192 \pm 0.04$ \\
\hline & S4 & $65 \pm 2.2$ & $5.52 \pm 0.08$ & $2.404 \pm 0.04$ \\
\hline & S5 & $60 \pm 2.1$ & $5.56 \pm 0.12$ & $2.356 \pm 0.04$ \\
\hline \multirow{4}{*}{$\begin{array}{l}\text { Hibiscus } \\
\text { rosasinensis }\end{array}$} & $\mathrm{S} 2$ & $45 \pm 2.1$ & $3.60 \pm 0.08$ & $0.854 \pm 0.03$ \\
\hline & S3 & $50 \pm 2.2$ & $4.20 \pm 0.07$ & $1.432 \pm 0.05$ \\
\hline & S4 & $69 \pm 2.1$ & $4.36 \pm 0.05$ & $1.412 \pm 0.03$ \\
\hline & S5 & $60 \pm 2.1$ & $4.42 \pm 0.06$ & $0.992 \pm 0.05$ \\
\hline \multirow{4}{*}{$\begin{array}{l}\text { Mirabilis } \\
\text { jalapa }\end{array}$} & $\mathrm{S} 2$ & $40 \pm 2.2$ & 4. $12 \pm 0.06$ & $2.312 \pm 0.04$ \\
\hline & S3 & $42.2 \pm 2.4$ & $4.20 \pm 0.06$ & $3.192 \pm 0.05$ \\
\hline & S4 & $50 \pm 2.2$ & $4.52 \pm 0.06$ & $3.494 \pm 0.04$ \\
\hline & S5 & $45 \pm 2.3$ & $4.54 \pm 0.07$ & $3.252 \pm 0.03$ \\
\hline
\end{tabular}

(S-2-early developmental stage, S-3- petal partly opened but fully developmental stage, S-4- fully opened flower with late developmental stage and S-5- petals at the senescence stage) 
Table.2 Variation in total flavonoid, sugar and protein content in Petals of test flowers at different developmental stages

(Values are means of 5 replicates \pm S.E.M)

\begin{tabular}{|l|c|c|c|c|}
\hline $\begin{array}{l}\text { Name of } \\
\text { flower species }\end{array}$ & $\begin{array}{c}\text { Develop- } \\
\text { mental } \\
\text { stages }\end{array}$ & $\begin{array}{c}\text { Total flavonoid } \\
\text { (mg/g dry wt) }\end{array}$ & $\begin{array}{c}\text { Total sugar (mg/g } \\
\text { dry wt) }\end{array}$ & $\begin{array}{c}\text { Total protein } \\
\text { (mg/g fr.wt) }\end{array}$ \\
\hline \multirow{4}{*}{ Rosa indica } & S2 & $7.80 \pm 0.2$ & $2.140 \pm 0.04$ & $0.390 \pm 0.02$ \\
\cline { 2 - 5 } & S3 & $9.60 \pm 0.2$ & $2.280 \pm 0.04$ & $0.380 \pm 0.01$ \\
\cline { 2 - 5 } & S4 & $10.06 \pm 0.5$ & $2.360 \pm 0.05$ & $0.360 \pm 0.01$ \\
\cline { 2 - 5 } $\begin{array}{l}\text { Clitoria } \\
\text { ternatea }\end{array}$ & $\mathrm{S} 5$ & $10.02 \pm 0.4$ & $2.260 \pm 0.04$ & $0.300 \pm 0.01$ \\
\cline { 2 - 5 } & $\mathrm{S} 2$ & $8.80 \pm 0.3$ & $1.980 \pm 0.02$ & $0.280 \pm 0.01$ \\
\cline { 2 - 5 } & $\mathrm{S} 3$ & $12.28 \pm 0.5$ & $2.140 \pm 0.04$ & $0.250 \pm 0.02$ \\
\hline \multirow{4}{*}{$\begin{array}{l}\text { Hibiscus } \\
\text { rosasinensis }\end{array}$} & $\mathrm{S} 4$ & $12.96 \pm 0.5$ & $2.220 \pm 0.04$ & $0.230 \pm 0.01$ \\
\cline { 2 - 5 } & $\mathrm{S} 5$ & $12.40 \pm 0.2$ & $2.120 \pm 0.03$ & $0.220 \pm 0.01$ \\
\cline { 2 - 5 } & $\mathrm{S} 2$ & $6.20 \pm 0.4$ & $1.920 \pm 0.03$ & $0.360 \pm 0.01$ \\
\hline \multirow{4}{*}{$\begin{array}{l}\text { Mirabilis } \\
\text { jalapa }\end{array}$} & $\mathrm{S} 4$ & $10.02 \pm 0.4$ & $2.340 \pm 0.05$ & $0.340 \pm 0.01$ \\
\cline { 2 - 5 } & $\mathrm{S} 5$ & $9.72 \pm 0.2$ & $2.204 \pm 0.05$ & $0.300 \pm 0.01$ \\
\cline { 2 - 5 } & $\mathrm{S} 2$ & $10.32 \pm 0.3$ & $1.298 \pm 0.02$ & $0.260 \pm 0.01$ \\
\cline { 2 - 5 } & $\mathrm{S} 3$ & $11.04 \pm 0.5$ & $1.422 \pm 0.03$ & $0.250 \pm 0.01$ \\
\hline
\end{tabular}

(S-2-early developmental stage, S-3- petal partly opened but fully developmental stage, S-4-fully opened flower with late developmental stage and S-5- petals at the senescence stage)

More than 540 complete structures of anthocyanin have been identified and each anthocyanin consists of an aglycone (anthocyanidin), sugars and in many cases acyl groups (Andersen and Jordheim, 2006). Anthocyanins are modified into different compounds by glycosylation, methylation and acylation which are very necessary for their stabilization as vacuolar anthocyanins.

Glycosylation is an important modification for increasing the hydrophilicity and stability of anthocyanins, because the anthocyanidins are inherently unstable under the physiological conditions. Anthocyanidins are generally $\mathrm{O}$-glycosylated at the $\mathrm{C}-3$ position with the addition of glucose by the activities of uridine flavonoid glycosyl transferase (UFGTase) (Ford et al., 1998). In the plant kingdom normally, O-glycosylation can stabilize the anthocyanin which can be stored in vacuole without hydrolysis of anthocyanins.

The development of anthocyanin in leaves, fruits and flowers are characterised by a slow increase at early stage of the organ growth followed by a sharp abrupt and substantial rise to a maximum and finally by a slow decrease until the death of the plant cell (Stickland, 1972 and Janna et al., 2006). They are of opinion that maximum anthocyanin accumulation takes place late in maturity when plastid pigments undergo rapid decomposition. The synthesis of anthocyanin during floral formation and its accumulation in petals are interlinked with development of petals. Similar results were found by Mahapatra et al., (2014) in Mirabilis jalapa; Justesen et al., (1997) in Campanula 
isophylla and Stickland (1972) in Chrysanthemum flowers. In the present experimental results, it was found that the anthocyanin pigment content was significantly higher before flowers started to open and subsequently decreased after blooming of flowers (S-5 stage).

Water accumulation in vacuoles play an important role in anthocyanin expression, as water in vacuoles leads to hydrolysis of various macromolecules which later accelerate the conversion of starch into sugar that take part in synthesis and expression of anthocyanin in petals (Stickland, 1972 and Woodward, 1972). So, there is a better correlation between petal water-content and the anthocyanin production during the floral development. The petals of S-3 stage (the partly opened with fully-formed petals) and S-4 stage (fully opened) were rich with anthocyanin pigments where as in S-5 stage (partly decayed late developmental) the pigment content in petals was comparatively less than the other developmental stages but more than S-2 stage. Maximum anthocyanin accumulation was found in petals in all flowers at late matured stage while the plastids undergo rapid decomposition. This implies that almost all the flowers at S-3 stage (fully formed but partly opened) attain their full matured form when the colours of the petals of the flowers become darker than the other floral stages. Degradation of anthocyanins, generally with advance of flower age has been observed in Campanula isophylla by Justesen et al., (1997) and in Chrysanthemum by Stickland, (1972). Results of present investigation revel that the total anthocyanin content was maximum at S-3 stage in Rosa indica and $H$. rosasinensis while it was maximum at S-4 stage in $C$. ternatea and $M$. jalapa. The minimum content was in S-5 and S-2 stage respectively in all the test flowers. This variation might be due to varietal differences or internal genetic factors.

The total flavonoid content was maximum at S-4 stage and minimum in S-2 stage in petals of all test flowers. The total flavonoid content was found to be maximum in Clitorea ternatea followed by $M$. jalapa, Rosa indica and Hibiscus rosa-sinensis respectively. The order of total flavonoid content was in the following manner: S-4 > S-5 > S-3 > S-2 in all the test flowers. The experimental results corroborate with the findings of Schmitzer et al., (2010) and Castellarin et al., (2007) in other varieties of Rosa indica flower.

\section{Variation in total sugar and protein content in petals}

Carbohydrates participate in a number of metabolic processes during the growth and development of the flowers. The flower bud is a major sink for assimilates under favourable conditions, whereas a shortage of carbohydrates often leads to arrest the development. Since the petals are nearly achlorophyllous organs, very little photosynthesis occur in them and they depend entirely on adjacent calyx tissues/leaves for carbon source and osmotic components (Harris and Jaffcoat, 1972). Reducing sugar rather than sucrose were noted as the main constitute of sugar pool of the mature petals (Nichols, 1973). Several studies have shown that sugar level increases during petal development to a maximum at the stage of rapid cell expansion (Clement et al., 1996). The contents of reducing sugars in younger petals was lower and increased rapidly from the stage when petals started to split reaching to maximum at full bloom (Sood et al., 2006).The role of sugars in flower development may be multifunctional as they act as an energy source (Moalem-Beno et al., 1997), osmotic regulators (Bieleski, 1993) and as precursors for metabolic processes and the increased osmoticum in the petals have been suggested to be the driving force for 
their expansion (Ho and Nichols, 1977). It has been suggested that soluble sugars in rose flowers are important as osmotically active substances in promoting petal growth and development (Sood et al., 2006). Many studies have shown that sugars act as signaling molecules in higher plants (NetaSharir et al., 2000) and in most case sugar phosphorylation by hexokinase are required to initiate signal transduction (Jang and Sheen, 1997 and Penna et al., 2006). The promotive effect of sugars on petal growth seems to be a general phenomenon. However, it is still not clear whether sugars act in all cases as specific signaling molecules to promote gene expansion or via another mechanism.

Starch in the petals acts as a reservoir of carbon at the times of need. Sood et al., (2006) noticed a steady decline in starch content as the flower of 2 varieties of rose species reached their full blooming stage. Similar findings were observed during maturation of the perianth leaves of Gladiolus flowers (Ferreira et al., 1986) and in ornamental rose, (Ho and Nochols, 1977). In Carnation, the starch content in petals declined as the flowers developed (Tirosh and Mayak, 1988), however, the extent of decline was the greatest in cut flowers held in water, least in attached and intermediate in flowers held in sucrose solution. Further, as a function of stages of flower development in Carnation, starch content decreased and soluble sugars increased concomitantly and hence, increased sink strength of the developing flower is coordinated with increased mobilization of starch reserves as well as supply of photosynthates.

Nagar et al., (2007) and Kumar and Singh (2012) reported that low supply of carbohydrates to floral buds considerably check the development of flower. The present experimental observations exhibited similar trend as was found by the above authors in $H$. rosasinensis flower. According to Clement et $a l$. , (1996) sugar level increases during petal development and reaches to maximum at rapid cell expansion stage of the petal i.e. full bloom stage which indicates that sugar plays a multi-functional role in the flower development. Nichols (1973) also had reported that the sugar level in petals decreases after mature stage due to onset of senescence of petals. Similarly it was reported that the energy source and osmotic regulator of the cells of petals decrease on the advancement of petal age (Sood et al., 2006).

In the present investigation the total sugar content in petals exhibited the following order: S-4 > S-3 > S-5 > S-2 in all test flowers which corroborate with the above reports of above mentioned researches.

During the flower development process, the total protein content varies from one developmental stage to another, which show highest value in the younger stage and lowest in the later stages of petal formation Sood $e t$ al., (2006). Nagar et al., (2007), Eason and Webster (1995) and Ley-Yee and Stead (1992) reported that the amount of protein content was highest in the youngest stage and lowest in the later stages of petal development in two species of roses.

Loss of protein has been reported in day-lily petals during the flower development process by Ley-Yee and Stead (1992) and in Sandersonia flowers by Eason and Webster (1995). Sood et al., (2006) found that the amounts of protein and RNA per unit dry weight were highest in the youngest stage and lowest in later stages of development in two species of rose. Loss of RNA might be due to decrease in the rates of synthesis or increase in the activity of RNase but latter increase might be large. In Ipomoea, RNA contents started decreasing just before full bloom, whereas the sharp increase of RNase is 
evident only after beginning of colour fading indicating that the first stage in decline of RNA is caused by reduced synthesis (Matile and Winkenbach, 1971).

Substrates Trans located to the petals on the one hand (Ho and Nichols, 1977) and out of the flower to other plant parts on the other. The gradual decline in respiration of rose petals and decrease in respiration efficiency may be due to progressive inability of mitochondria to utilize the substrates.

In the present investigation it was observed that the total protein contents were maximum in S-2 stage and minimum in S-5 stage in petals of experimented test flowers. The order of total protein content in test flowers was: Rosa indica > Hibiscus rosasinensis> Clitorea ternatea > Mirabilis jalapa. The findings corroborate with the observation of above reports.

In nutshell, it can be concluded that biochemical component and pigments in petal of different flower studied are varies from flower to flower basing on their developmental stages. Hence, it can be suggested that the procurement of colour pigments from petal of different coloured flowers at appropriate level, basing on developmental stages of flowers is highly essential for further processing and manipulation through screening and evaluation. The colour pigment manipulation and utilization in food market, dye and pharmaceutical industries will create new fields for sustainable health aspect and alternatives technology for better green environment.

\section{Acknowledgment}

The authors wish to express sincere thanks to the Principal, Aska Science College, Aska for his encouragement and providing necessary facilities.

\section{References}

Andersen, M. and Jordheim, M., 2006.The anthocyanins. In: Flavonoids: Chemistry, Biochemistry and Applications, (Eds.Andersen, $\mathrm{M}$ and Markham K.R), CRC Press, Boca Raton, pp 471-553.

Asen, S., Norris, K.H. And Stewart, R.N., 1971. Effect of $\mathrm{pH}$ and Concentration of the anthocyanin-flavanol co-pigment complex on the colour of 'Better Times' Roses. J. American Society for Horticultural Science, 96:770-773.

Bieleski, R.L., 1993. Fructan hydrolysis drives petal expansion in the ephemeral day lily flower.

Bohm, B. A., 1994. The miner Flavonoids, in the Flavonoids: Advances in research since 1986. (Ed. Harborne, J.B.), pp. 387-440. Chapman and Hall, London, UK.

Bouvier, F., Suire, C., Mutterer, J. and Camara, B., 2003 (a). Oxidative remodeling of chromoplast carotenoids: identification of the carotenoid dioxygenase CsCCD and CsZCD genes involved in crocus secondary metabolite biogenesis. Plant Cell, 15: 4762.

Brouillard, R. and Dangles, O., 1993. Flavonoids and Flower colour. In: The flavonoids Advances in research since 1986. (Ed. J.B. Harborne), Chapman and Hall,Ltd, London. pp 565-586.

Castellarin, S.D., Pfeiffer, A., Sivilotti, P., Degan, M., Peterlunger, E. and Di Gaspero, G., 2007. Transcriptional regulation of anthocyanin biosynthesis in ripening fruits of Grapevine under seasonal water deficit. Plant Cell Environ. 30(11): 1381-99.

Chirbago, C. and Francis, F. J., 1970. An anthocyanin recovery system from Cranberry pomace. J. Am. Soc. Hort. Sci., 9: 223.

Clement, M., Burrus, S. and Audran, J. C., 1996. Floralorgan growth and Carbohydrate content during pollen development in lilium. American j. Botany, 83: 459-469.

Eason, J. R. and Webster, D.1995. Development and senescence of Sandersonia aurantiaca 
(Hook.) flowers. Scientia Horticulturae, 63:113-121

Ferreira, D.I., Van der merwe, J.J and De Swart, G.H., 1986. Starch metabolism in flowers of senescing Gladiolus inflorescences. Acta Horticulturae, 177: 203-210.

Ford, C.M., Boss, P.K. and Haj, P. B., 1998. Cloning and characterization of Vitis vinifera UDP-glucose: flavonoid 3-Oglycosyl transferase, a homologue of the enzyme encoded by the maize bronze-1 locus that may primarily serve to glucosylate anthocyanidins in vivo. J. Biol. Chem., 273: 9224-9233.

Fuleki, T. and Francis, F.J., 1968.Quantitative methods for anthocyanins extraction and determination of total anthocyanin in Cranberry juice. J. Food Sci., 33:72-78.

Halevy, A.H. and Mayak, S., 1981. Sensscence and post-harvest physiology of cut flower, part-II. Horticulture review, 3: 59-143.

Harborne, J. B., 1998(a). Methods of plant analysis. In: Phytochemical methods, a guide to modern techniques of plant analysis, third edition, Springer Int. Edition, Chapter 1: 4-34.

Harris, G.P. and Jaffcoat, G., 1972. Distribution of $\mathrm{C}^{14}$-labeled Assimilates in flowering Carnation plants. J. Horticultural Science, 47: 25-35.

Ho, L.C. and Nichols, R., 1977. Translocation of $\mathrm{C} 14-$ Sucrose in relation to changes in carbohydrate content in rose corollas cut at different stages of development.Annals of Botany, 41: 227-242.

Jang, J.C. and Sheen, J., 1997. Sugar sencing in higher plants. Trends in plant science, 2: 208-213.

Janna O.A.; Khairul A.; Maziah M. and Mohd, Y., 2006. Flower pigment analysis of Melastoma malabathricum. African J. Biotechnology, 5 (2): 170-174.

Justesen, H., Andersen, A.S. and Brandt, K., 1997.Accumulation of Anthocyanins and Flavones during Bud and Flower Development in Campanula isophylla. Annals of Botany, 79:355-360.

Khatiwora I, Elija, Vaishali, B., Adsul, Manik. Kulkarni, M., Deshpande, N.R. and
Kashalkar, R.V., 2010. Spectroscopic determination of total Phenol and flavonoid contents of Ipomoea carnea. International J. Chem. Tech. Research (IJCRGG), 2(3): 1698-1701.

Kiranmai, M., Kumar, M. and Mohammed, I., 2011. Comparison of total flavanoid content of Azadirachta indica root bark extracts prepared by different methods of extraction.Research J. Pharmaceutical, Biological and Chemical Sciences, 2: 254261.

Kirca, A., Ôzkan, M. and Cemeroğlu, B., 2007. Effects of temperature, solid content and $\mathrm{pH}$ on the stability of black carrot anthocyanins. Food Chemistry, 101(1): 212-218.

Kuiper, D., van Reenen, H.S., Ribot, S.A., 1996. Characterisation of flower bud opening in roses: A comparison of Madelon and Sonia roses. Postharvest Biol. Technol. 9:75-86.

Kumar Anil and Singh Ashatha, 2012. Review on Hibiscus rosa sinensis, Intl. J. Res. in Pharmaceutical and Biomedical Sciences, 3(2): 534-538.

Ley-Yee, M., Stead, A.D, Reid, M.S., 1992. Flower senescence in Day lily (Hemero callis).

Lowry, O.H., Rosdbrough, N. J., Farr, A. L. and Randall, R. J., 1951. Protein measurement with the Folin phenol reagent.J. Biological Chemistry, 193: 265- 275.

Mahadevan, A. and Sridhar, R., 1998. Methods in physiological plant pathology. 5th ed. Sivakami Publication, Madras, India.

Mahapatra, S., Padhy, B. and Behera P. K., 2014. Relation of flower colour, anthocyanin concentration and the environmental factors, Asian Journal. Of Microbiol. Biotech. Env. Sci., 16 (3):793798.

Martin,C. and Gerats, T.,1993.Control of pigment biosynthesis genes during petal development. Plant cell, 5:1253-1264.

Matile, P.H. and Winkenbach, T., 1971. Function of lysosome and lysosomal enzyme in the senescing corolla of morning glory (Ipomoea purpurea). J. Experimental 
Botany 22: 759-771.

Moalem-Beno, D.; Tamari, G.; Leitner-Dragon, Y.; Borochov, A. and Weiss, D., 1997. Sugar dependent gibberelin induced chalcone synthetase gene expression in Petunia corolas. Plant physiology, 13: 419424.

Nagar, P.K., Sharma, M., Pati, P.K. and Ahuja, P.S., 2007. Rose: some important findings with special reference to Physiology of flowering. Floriculture and Ornamental Biotechnology, 1(2):102-114.

Neta-Sharir, I., Shoseyov, O. and Weiss, D., 2000. Sugar enhance the expression of giberellin-induced genes in developing Petunia flower. Physiologia Plantarum, 9: 196-202.

Nichols, R., 1973.Senescence of the cut carnation flower: Respiration and sugar status. J. Horticultural science, 48:111-121.

Penna, S., Teixeira da Silva, J.A. and Anant, B.V., 2006. Plant abiotic stress, sugars and Physiologia Plantaram, 86: 308-314. Plant physiology, 103: 213-219.

Schmitzer, V., Veberic, R., Osterc, G., and Franci S., 2010. Color and Phenolic content changes during flower development in Ground cover Rose. J. American Society for Hort. Sci., 135 (3): 195-202.

Sood, S., Vyas, D. and Nagar. P.K., 2006. Physiological and biochemical studies during flower development in two rose species. Scientia Hort, 108: 390-396.

Stickland, R. G., 1972. Changes in anthocyanin, carotenoid, chlorophyll, and protein in developing florets of the Chrysanthemum. Annals of Botany, 36: 459-469.

Teixeira da Silva, J.A., 2006. Ornamental cut flower: Physioogy in practice. In:
Floriculture, Ornamental and plant biotechnology: Advances and Tropical issues. (Ed. Teixeira da Silva, J.A.), (1 ${ }^{\text {st }}$ Edn) I: pp.124-140. Global Science Books, Isleworth, UK.

Tirosh, T. and Mayak, S., 1988. Changes in starch content during the development of carnation petals. J. plant physiology, 133: 361-363. transgenics: A perspective. In: Floriculture, Ornamental and Plant biotechnology: Advances and topical issues (1st Edn, Vol.II), (Ed. Teixeira da Silva, J.A.), pp. 86-94.Global Science Books, Isleworth, UK.

Valentina, S., Robert, V., Gregor, O. and Franci, S., 2010. Colour and Phenolic content changes during flower development in ground cover rose. J. Amer. Soc. Hort. Sci., 135(3):195-202.

Vishnevetsky, M., Ovadis, M. and Vainstein, A., 1999. Carotenoid Sequestration in plants: the role of carotenoid-associated proteins. Trends in Plant Sci., 4: 232-235.

Wasim, S., Inayatullah, T., Sheikh, T. I.and Mustaq, A. B., 2011. Physiological and biochemical changes associated with flower development and senescence in so far unexplored Helleborus orientalis Lam. Physiol. Mol. Biol. Plants, 17(1): 33-39.

Winefield, C., 2002. The final steps in anthocyanin formation: A story of modification and sequestration. Adv. Bot. Res., 37: 55-74.

Woodward, J.R., 1972, Physical and chemical changes in developing strawberry fruits. J. of Science of Food and Agriculture, 23 (4): 465-473.

\section{How to cite this article:}

Adhikary, S.P. 2017. Analysis of Various Floral Components at Different Developmental Stages of the Flower. Int.J.Curr.Microbiol.App.Sci. 6(7): 2053-2068.

doi: https://doi.org/10.20546/ijcmas.2017.607.243 